\title{
Cannabinoid type 2 receptors mediate a cell type-specific self-inhibition in cortical neurons
}

\author{
Alexander Stumpf ${ }^{1}$, Daniel Parthier ${ }^{1}$, Rosanna P. Sammons ${ }^{1}$, A. Vanessa Stempel ${ }^{1,2}$, Jörg \\ Breustedt ${ }^{1}$, Benjamin R. Rost ${ }^{1,3}$, Dietmar Schmitz ${ }^{1,3,4,5,6,7}$
}

\section{Affiliations}

1 Neuroscience Research Center, Charité-Universitätsmedizin Berlin, Germany

2 Sainsbury Wellcome Centre for Neural Circuits and Behaviour, University College London, UK

3 German Center for Neurodegenerative Diseases (DZNE), Berlin, Germany

4 Berlin Institute of Health, Berlin, Germany

5 Bernstein Center for Computational Neuroscience Berlin, Germany

6 Cluster of Excellence NeuroCure, Berlin, Germany

7 Einstein Center for Neurosciences, Berlin, Germany

\section{Correspondence should be addressed to}

Prof. Dr. Dietmar Schmitz

Charité - Universitätsmedizin Berlin

Charitéplatz 1; 10117 Berlin, Germany

Telefone: +4930450539054

Fax: +49 30450539916

dietmar.schmitz@charite.de

\footnotetext{
Abbreviations: $\mathrm{CB}_{1} \mathrm{R}$ and $\mathrm{CB}_{2} \mathrm{R}$, cannabinoid receptors type 1 and 2; SSI, slow self-inhibition; GIRK channel, $\mathrm{G}$ protein-coupled inward-rectifying $\mathrm{K}^{+}$channel; GPCR, G protein-coupled receptors; DSI, depolarization-induced suppression of inhibition; DSE, depolarization-induced suppression of excitation; CNS, central neural system; APs, action potentials; 2-AG, 2-arachidonoylglycerol; LTS, low -threshold spiking interneurons; NBC, sodium/bicarbonate co-transporter; PC, pyramidal cell; RSNPC, regular spiking non-pyramidal cell; FS, fast spiking interneuron; ACSF, artificial cerebrospinal fluid; $V_{m}$, membrane potential; NE, noladin ether;
} 


\section{Abstract}

Endogenous cannabinoids are diffusible lipid ligands of the main cannabinoid receptors type 1 and 2 $\left(C_{1} R\right.$ and $\left.C B_{2} R\right)$. In the central nervous system endocannabinoids are produced in an activitydependent manner and have been identified as retrograde modulators of synaptic transmission. Additionally, some neurons display a cell-autonomous slow self-inhibition (SSI) mediated by endocannabinoids. In these neurons, repetitive action potential firing triggers the production of endocannabinoids, which induce a long-lasting hyperpolarization of the membrane potential, rendering the cells less excitable. Different endocannabinoid receptors and effector mechanisms have been described underlying SSI in different cell types and brain areas. Here, we investigate SSI in neurons of layer $2 / 3$ in the somatosensory cortex. High-frequency bursts of action potentials induced SSI in pyramidal cells (PC) and regular spiking non-pyramidal cells (RSNPC), but not in fast-spiking interneurons (FS). In RSNPCs the hyperpolarization was accompanied by a change in input resistance due to the activation of $G$ protein-coupled inward-rectifying $K^{+}$(GIRK) channels. $A C_{2} R$-specific agonist induced the long-lasting hyperpolarization, whereas preincubation with a $\mathrm{CB}_{2} \mathrm{R}$-specific inverse agonist suppressed SSI. Additionally, using cannabinoid receptor knockout mice, we found that $\mathrm{SSI}$ was still intact in $\mathrm{CB}_{1} \mathrm{R}$-deficient but abolished in $\mathrm{CB}_{2} \mathrm{R}$-deficient mice. Taken together, we describe an additional SSI mechanism in which the activity-induced release of endocannabinoids activates GIRK channels via $\mathrm{CB}_{2} \mathrm{Rs}$. These findings expand our knowledge about cell type-specific differential neuronal cannabinoid receptor signaling and suggest $\mathrm{CB}_{2} \mathrm{R}$-selective compounds as potential therapeutic approaches. 


\section{Abstract}

Endogenous cannabinoids are diffusible lipid ligands of the main cannabinoid receptors type 1 and $2\left(C B_{1} R\right.$ and $\left.C B_{2} R\right)$. In the central nervous system endocannabinoids are produced in an activity-dependent manner and have been identified as retrograde modulators of synaptic transmission. Additionally, some neurons display a cellautonomous slow self-inhibition (SSI) mediated by endocannabinoids. In these neurons, repetitive action potential firing triggers the production of endocannabinoids, which induce a long-lasting hyperpolarization of the membrane potential, rendering the cells less excitable. Different endocannabinoid receptors and effector mechanisms have been described underlying SSI in different cell types and brain areas. Here, we investigate SSI in neurons of layer $2 / 3$ in the somatosensory cortex. High-frequency bursts of action potentials induced SSI in pyramidal cells (PC) and regular spiking non-pyramidal cells (RSNPC), but not in fast-spiking interneurons (FS). In RSNPCs the hyperpolarization was accompanied by a change in input resistance due to the activation of $\mathrm{G}$ protein-coupled inward-rectifying $\mathrm{K}^{+}(\mathrm{GIRK})$ channels. $\mathrm{A} \mathrm{CB}_{2} \mathrm{R}$-specific agonist induced the long-lasting hyperpolarization, whereas preincubation with a $\mathrm{CB}_{2} \mathrm{R}$-specific inverse agonist suppressed SSI. Additionally, using cannabinoid receptor knockout mice, we found that $\mathrm{SSI}$ was still intact in $\mathrm{CB}_{1} \mathrm{R}$-deficient but abolished in $\mathrm{CB}_{2} \mathrm{R}$-deficient mice. Taken together, we describe an additional SSI mechanism in which the activity-induced release of endocannabinoids activates GIRK channels via $\mathrm{CB}_{2}$ Rs. These findings expand our knowledge about cell type-specific differential neuronal cannabinoid receptor signaling and suggest $\mathrm{CB}_{2} \mathrm{R}$-selective compounds as potential therapeutic approaches. 


\section{Introduction}

The endocannabinoid system is one of the main neuromodulatory systems in the vertebrate central nervous system (CNS). Endocannabinoids are membrane-derived lipid molecules that mainly, albeit not exclusively, exert their effects by acting via $\mathrm{G}$ proteincoupled receptors (GPCR) (Kano, 2009). While $\mathrm{CB}_{1} \mathrm{Rs}$ are one of the most widely expressed GPCRs in the $\mathrm{CNS}, \mathrm{CB}_{2} \mathrm{Rs}$ were traditionally referred to as peripheral endocannabinoid receptors, since their expression was primarily detected in cells of the immune system (Munro et al., 1993).

The best-studies effects of endocannabinoids in the CNS are two forms of short-term synaptic plasticity: depolarization-induced suppression of inhibition (DSI) and excitation (DSE) (Kreitzer and Regehr, 2001; Ohno-Shosaku et al., 2001; Wilson and Nicoll, 2001). In both DSI and DSE, endocannabinoids are produced by the postsynaptic cell and retrogradely activate presynaptic $C B_{1} R$ s. Further, numerous forms of $C B_{1} R$-dependent synaptic long-term plasticity have been described, with endocannabinoids being involved in both long-term potentiation (Gómez-Gonzalo et al., 2015; Maglio et al., 2017; Wang et al., 2016) and long-term depression (Chevaleyre and Castillo, 2003; Gerdeman et al., 2002; Safo and Regehr, 2005; Sjöström et al., 2003). However, in recent years several publications have provided functional evidence for the presence of $\mathrm{CB}_{2} \mathrm{Rs}$ in cells of the $\mathrm{CNS}$, where $\mathrm{CB}_{2} \mathrm{Rs}$ exert inhibitory effects (García-Gutiérrez et al., 2013, 2012; Gong et al., 2006; Kim and Li, 2015; Onaivi, 2007; Stempel et al., 2016).

In addition to their synaptic effects, a plethora of non-synaptic and cell-autonomous forms of endocannabinoid modulation exists (Bacci et al., 2004; den Boon et al., 2012; Stempel et al., 2016). For example, layer $2 / 3$ pyramidal neurons and layer 5 lowthreshold spiking (LTS) interneurons in the somatosensory cortex express a $C_{1} B_{1} R$ dependent form of self-inhibitory plasticity, namely SSI (Bacci et al., 2004; Marinelli et 
al., 2009). In both cell types, trains of action potentials (APs) were described to induce the production of the endocannabinoid 2-arachidonoylglycerol (2-AG) and subsequent $\mathrm{CB}_{1} \mathrm{R}$ activation within the same cell. This leads to a $\mathrm{G}$ protein-dependent opening of GIRK channels, which hyperpolarizes the cell. In contrast, in hippocampal CA3 pyramidal cells, activation of $\mathrm{CB}_{2} \mathrm{Rs}$ has been shown to cause a long-lasting hyperpolarization of the cells that alters local network rhythms (Stempel et al., 2016). This form of self-inhibition is phenotypically similar to cortical SSI but depends on the downstream modulation of the sodium/bicarbonate co-transporter (NBC).

At present, it is not known if SSI in different types of cortical neurons exclusively depends on $\mathrm{CB}_{1} \mathrm{Rs}$ or whether $\mathrm{CB}_{2} \mathrm{Rs}$ may also contribute to its induction. Furthermore, it is not clear exactly which cell types are capable of inducing SSI and by which mechanism it is implemented.

In this study, we investigate cell-autonomous SSI in neocortical neurons of the mouse somatosensory cortex layer 2/3. We show that trains of APs evoke a long-lasting hyperpolarization in pyramidal cells (PCS) and regular spiking non-pyramidal cells (RSNPCs), but not in fast spiking interneurons (FS). In RSNPCs, this self-inhibition is exclusively mediated by activation of $\mathrm{CB}_{2} \mathrm{R}$, demonstrated both by pharmacological tools and knockout (KO) mice, and leads to a hyperpolarization via activation of GIRK channels. Our findings add to the understanding of the highly complex function of the endocannabinoid neuromodulatory system, and provide additional evidence for functional expression of $\mathrm{CB}_{2} \mathrm{R}$ in the CNS. 


\section{Materials and Methods}

\subsection{Ethical Statement and Animal Handling}

Animal husbandry and experimental procedures were performed in accordance with the guidelines of local authorities (Berlin, Germany), the German Animal Welfare Act, and the European Council Directive 86/609/EEC. $\mathrm{CB}_{1} \mathrm{R}$ - and $\mathrm{CB}_{2} \mathrm{R}$-deficient mice (Buckley et al., 2000; Zimmer et al., 1999) were maintained on a C57BL/6n genetic background, and homozygous KO mice and their wild-type (WT) littermates were obtained from heterozygous breeding. Animals were housed on a $12: 12 \mathrm{~h}$ reversed day-night cycle with food and water ad libitum.

\subsection{Preparation of brain slices}

Coronal slices were prepared from the somatosensory cortex of $C 57 \mathrm{BL} 6 / \mathrm{n}$ mice, $\mathrm{CB}_{1} \mathrm{R}$ or $\mathrm{CB}_{2} \mathrm{R}$ KO mice and their WT-littermates aged postnatal day 21-35. Animals were anesthetized with isoflurane and decapitated. Brains were removed and transferred to ice-cold sucrose-based artificial cerebrospinal fluid (sACSF) containing in mM: $87 \mathrm{NaCl}$, $26 \mathrm{NaHCO}_{3}, 50$ sucrose, 10 glucose, $2.5 \mathrm{KCl}, 1.25 \mathrm{NaH}_{2} \mathrm{PO}_{4}, 3 \mathrm{MgCl}_{2}, 0.5 \mathrm{CaCl}_{2}$. Tissue blocks were mounted on a vibratome (Leica VT 1200S, Leica Microsystems), cut at $300 \mu \mathrm{m}$ thickness, and stored in an interface chamber. The interface chamber was perfused with ACSF containing in mM: $119 \mathrm{NaCl}, 26 \mathrm{NaHCO}_{3}, 10$ glucose, $2.5 \mathrm{KCl}, 1$ $\mathrm{NaH}_{2} \mathrm{PO}_{4}, 2.5 \mathrm{CaCl}_{2}$ and $1.3 \mathrm{MgCl}_{2}$. Slices were incubated for at least $60 \mathrm{~min}$ before recordings started. All ACSF solutions were equilibrated with carbogen $\left(95 \% \mathrm{O}_{2}\right.$ and $5 \%$ $\left.\mathrm{CO}_{2}\right)$.

\subsection{Slice electrophysiology}

Whole-cell current-clamp recordings were performed in layer $2 / 3$ of somatosensory cortex with a $\mathrm{KMeSO}_{3}$-based intracellular solution (containing in $\mathrm{mM}: 130 \mathrm{KMeSO}_{3}, 10$ 
KCl, 10 HEPES, 4 NaCl, 4 Mg-ATP, 0.5 Na-GTP, 5 Na-Phosphocreatine, $0.1 \%$ Biocytin), using a Multiclamp 700B amplifier (Molecular Devices). Data were low-pass filtered at 3 $\mathrm{kHz}$ and sampled at $10 \mathrm{kHz}$. Neurons were identified visually with infrared differential interference contract (IR-DIC) optics on an Olympus BX-51 WI microscope. Interneurons were differentiated from PCs based on two criteria: a lack of apical dendrite projecting towards the pial surface, and horizontally orientated and spherical shaped somata compared to the pyramidal shaped somata of PCs. Experiments were only performed if cells had a resting membrane potential more hyperpolarized than $-55 \mathrm{mV}$ (without correction for liquid junction potential) and a series resistance below $25 \mathrm{M} \Omega$. Bridge balance and pipette capacitance compensation was performed throughout the recording. Cells were characterized by recording their membrane response and firing pattern by applying hyperpolarizing and depolarizing current steps $(-200$ to $+600 \mathrm{pA}$, increment: 40 pA, 1 s). Fast-spiking interneurons showed high frequency AP firing (>200 $\mathrm{Hz}$ ) with no frequency adaptation. Both RSNPCs and PCs showed moderate spiking frequency $(20-60 \mathrm{~Hz})$ and increasing inter-spike intervals during the depolarization step. The AP slope ratio was calculated by dividing maximal positive slope with the maximal negative slope of the AP. Before inducing SSI, we manually adjusted the membrane potential to $-60 \mathrm{mV}$ by continuous somatic current injection and recorded a stable baseline for $2 \mathrm{~min}$. Cells that did not reach a stable baseline were excluded. SSI was induced either by eliciting AP trains with 2 ms long somatic current injection (10 AP trains, $20 \mathrm{~s}$ inter-train interval; $50 \mathrm{APs} /$ train at $100 \mathrm{~Hz}$ ) or by bath application of the $\mathrm{CB}_{2} \mathrm{R}$ agonist HU-308 (1 $\mu \mathrm{M}$, Tocris). Other pharmacological agents (10 $\mu \mathrm{M} \mathrm{SCH23390,} \mathrm{Tocris;}$ $10 \mu \mathrm{M}$ S0589, Sigma-Aldrich; $1 \mu \mathrm{M}$ SR 144528, Tocris) were applied to the bath and brain slices were preincubated for at least 10 min before recordings were performed. The input resistance was monitored by a 400 ms test-pulse of - -40 pA every $20 \mathrm{~s}$. 


\subsection{Data analysis and statistics}

Data were recorded and analyzed with Igor Pro (Wavemetrics) and Neuromatic software. Changes in membrane potential $\left(\Delta \mathrm{V}_{\mathrm{m}}\right)$ were calculated by subtracting the average membrane potential of $2 \mathrm{~min}, 60 \mathrm{~s}$ after the last AP train, from the baseline membrane potential. Changes in input resistance after SSI were calculated by normalizing the average input resistance after SSI induction to the average baseline input resistance. Cells were classified as responsive when $\Delta \mathrm{V}_{\mathrm{m}}$ was higher than three times the standard deviation of the baseline. Sample size is given as the number of recorded cells $(n)$. D'Agostino-Pearson normality test was performed to test individual datasets for normal distribution of the data points. Normally distributed datasets were compared using a two-tailed Student's t-test. Stated $p$-values refer to comparison of hyperpolarization amplitude $\left(\Delta V_{m}\right)$ between different datasets by using Student's t-test, unless otherwise stated. If datasets were not normally distributed a Mann-Whitney test was performed to compare the groups. Data are presented as mean \pm standard error of the mean (SEM). Box plots are shown as median with $25^{\text {th }}$ and $75^{\text {th }}$ percentile.

\subsection{Morphological reconstruction}

Biocytin-containing intracellular solution (0.1\% Biocytin) was used for post-hoc identification of the recorded neuron. After the recording, the brain slices were fixed overnight in $4 \%$ paraformaldehyde in PBS $(\mathrm{pH} 7.4)$ at $4^{\circ} \mathrm{C}$ before subsequent visualization with streptavidin conjugated with Alexa-488 (RRID:AB_2315383). Stained slices were imaged with a laser confocal microscope (Leica SP5 on a Leica DMI 6000) using a 20x or $63 x$ objective and a z-step size of $1 \mu \mathrm{m}$. Morphological reconstruction was performed using Neutube (Feng et al., 2015) and Fiji software (Schindelin et al., 2012). 


\section{Results}

\subsection{Cell type-specific hyperpolarization}

We performed whole-cell patch-clamp recordings from different cell types of layer $2 / 3$ in the somatosensory cortex. Based on their appearance in the IR-DIC image, we identified PCs by their eponymous soma shape and a prominent apical dendrite projecting towards the pial surface (Fig. 1A). Interneurons were differentiated by their horizontally orientated or spherical shaped somata and the absence of a prominent apical dendrite (Fig. 1B, 1C). Interneurons were further differentiated according to their firing properties (Table 1) into RSNPCs (Fig 1B) and FS interneurons (Fig. 1C). Physiological properties and firing patterns of PCs and RSNPCs were very similar (Table 1). In contrast, FS had a lower input resistance and showed a characteristic firing pattern (shorter AP half-width and high frequency firing), which allowed distinguishing these neurons from PCs and RSNPCs (Table 1).

Trains of APs elicited long-lasting SSI in PCs (Fig. 1D, G, J: $\Delta \mathrm{V}_{\mathrm{m}}:-4.1 \pm 1.5 \mathrm{mV}$ ) and in RSNPCs (Fig. $1 \mathrm{E}, \mathrm{H}, \mathrm{K}: \Delta \mathrm{V}_{\mathrm{m}}:-5.6 \pm 1.1 \mathrm{mV}$ ), but not in FS interneurons (Fig. $1 \mathrm{~F}, \mathrm{I}, \mathrm{L}: \Delta \mathrm{V}_{\mathrm{m}}$ : $0.7 \pm 0.5 \mathrm{mV})$.

According to our criteria (see Methods), $73 \%$ (8/11) of PCs and 71\% (15/21) of RSNPCs exhibited a significant hyperpolarization after AP trains, whereas none of the FS were responsive. Here, both responsive and non-responsive cells were included in averaged values and statistics (Fig. 1). Taken into account only responsive cells, PCs hyperpolarize by $-6.0 \pm 1.6 \mathrm{mV}$ and RSNPCs by $-7.6 \pm 1.0 \mathrm{mV}$ (data not shown).

Thus, trains of APs induced a long-lasting hyperpolarization exclusively in regular spiking cells (PCs and RSNPCs) in layer $2 / 3$ of the somatosensory cortex, but not in FS interneurons. We also assessed the stability of SSI and found that the SSI induced 
hyperpolarization of the membrane potential in RSNPCs was stable and lasted for the entire recording period of up to $40 \mathrm{~min}$ after induction (Suppl. Fig. 1A). Additional AP trains with an interval of two minutes that were applied after SSI had stabilized did not lead to any further significant additional hyperpolarization of the cells (Suppl. Fig. 1B and C).

\subsection{Mechanism underlying long-lasting hyperpolarization in regular spiking non-} pyramidal neurons

We have previously shown that trains of APs induce a cell-autonomous $\mathrm{CB}_{2} \mathrm{R}$-dependent SSI in hippocampal PCS by activation of a sodium/bicarbonate co-transporter (NBC) (Stempel et al. 2016). In contrast, both layer 2/3 PCs and layer 5 interneurons of the somatosensory cortex utilize an alternative mechanism in which activation of $\mathrm{CB}_{1} \mathrm{Rs}$ induces a GIRK channel-driven hyperpolarization (Bacci et al., 2004; Marinelli et al., 2009).

The cellular mechanisms of SSI have not been characterized before in layer 2/3 RSNPCs, despite the fact that of all cells in layer $2 / 3$, these show the most pronounced SSI (Fig. 1). Thus, we focused on RSNPCs to further investigate the SSI mechanism: in RSNPCs, the magnitude of hyperpolarization correlated with the decrease in input resistance (Fig. $2 \mathrm{~A})$, indicating an increase in ion channel conductance. Preincubation with an inhibitor of NBC (10 $\mu \mathrm{M}$ S0589) did not alter SSI in RSNPCs $\left(\Delta \mathrm{V}_{\mathrm{m}}:-4.4 \pm 3.4 \mathrm{mV} ; n=13 ; p=0.4\right.$ compared to control condition; data not shown). In contrast, preincubation with a GIRK channel blocker (10 $\mu \mathrm{M}$ SCH23390) prevented the long-lasting hyperpolarization (Fig. 2B-D: control $\Delta \mathrm{V}_{\mathrm{m}}$ : $-5.6 \pm 1.1 \mathrm{mV} ; 15 / 21$ responsive cells; $\mathrm{SCH} 23390 \Delta \mathrm{V}_{\mathrm{m}}:-0.2 \pm 1.1 \mathrm{mV}$; 1/11 responsive cells). Additionally, application of $\mathrm{SCH} 23390$ after $\mathrm{SSI}$ induction strongly 
depolarized the cells and increased input resistance, reversing the AP-induced effects (Fig. 2E-F). In contrast, only a weak baseline depolarization occurred when $\mathrm{SCH} 23390$ was applied to non-stimulated RSNPCs (Fig. 2G).

Thus, the AP-induced hyperpolarization in RSNPCs is mediated via activation of GIRK channels and not by the NBC.

\section{3 $\mathrm{CB}_{2}$ receptors mediate $\mathrm{SSI}$}

SSI was previously characterized as an endocannabinoid-dependent mechanism, in which either $\mathrm{CB}_{1} \mathrm{Rs}$ (Bacci et al., 2004; Marinelli et al., 2009) or $\mathrm{CB}_{2} \mathrm{Rs}$ (Stempel et al., 2016) induce a long-lasting hyperpolarization after periods of AP firing, via different mechanisms. The specific $\mathrm{CB}_{2} \mathrm{R}$ agonist $\mathrm{HU}-308(1 \mu \mathrm{M})$ mimicked the AP-induced hyperpolarization, whereas application of the endocannabinoid Noladin ether (NE, 300 $n M$ ), which displays selectivity for $\mathrm{CB}_{1}$ Rs over $\mathrm{CB}_{2} \mathrm{Rs}$ (Hanus et al., 2001), did not cause a hyperpolarization (Fig. $3 \mathrm{~A}$ and $\mathrm{B}$ : $\mathrm{HU}-308 \Delta \mathrm{V}_{\mathrm{m}}:-6.0 \pm 1.6 \mathrm{mV}, 8 / 11$ responding cells; NE: $\Delta \mathrm{V}_{\mathrm{m}}:-0.4 \pm 0.8 \mathrm{mV}, 3 / 10$ responding cells). Additionally, preincubation with the $\mathrm{CB}_{2} \mathrm{R}$ inverse agonist SR $144528 \quad(1 \mu \mathrm{M})$ prevented the AP-induced long-lasting hyperpolarization (Fig. $3 \mathrm{C}$ and $\mathrm{D}$ : control $\Delta \mathrm{V}_{\mathrm{m}}$ : $-5.6 \pm 1.1 \mathrm{mV}, 15 / 21$ responsive cells; $\mathrm{SR}$ 144528: $\Delta V_{m}:-0.8 \pm 0.6 \mathrm{mV}, 3 / 15$ responsive cells) indicating the involvement of $C_{2} R$ in SSI.

In order to verify this finding, we used transgenic $K O$ mice lacking $C_{1} R$ or $C_{2} R\left(C B_{1} R\right.$ KO and $\mathrm{CB}_{2} \mathrm{R} \mathrm{KO}$ ) and their corresponding littermates (Buckley et al., 2000; Zimmer et al., 1999) to further disentangle the involvement of the major cannabinoid receptors in APinduced SSI. In both $\mathrm{CB}_{1} \mathrm{R}$ KO mice and WT-littermates, trains of APs elicited a longlasting hyperpolarization of similar magnitude in RSNPCs (Fig. $4 \mathrm{~A}-\mathrm{C}: \mathrm{CB}_{1} \mathrm{R}$ KO: $\Delta \mathrm{V}_{\mathrm{m}}:-3.7$ $\pm 0.9 \mathrm{mV}, 12 / 17$ responsive cells; $\mathrm{CB}_{1} \mathrm{R} W \mathrm{WT}: \Delta \mathrm{V}_{\mathrm{m}}:-5.2 \pm 1.5 \mathrm{mV}, 7 / 10$ responsive cells). In 
contrast, $\mathrm{CB}_{2} \mathrm{R}$-deficient mice showed a marked reduction of $\mathrm{SSI}$, both in the $\mathrm{SSI}$ amplitude (Fig. 4D and E: $\mathrm{CB}_{2} \mathrm{R} \mathrm{KO}: \Delta \mathrm{V}_{\mathrm{m}}:-0.4 \pm 0.6 \mathrm{mV} ; \mathrm{CB}_{2} \mathrm{R} \mathrm{WT:} \Delta \mathrm{V}_{\mathrm{m}}:-3.6 \pm 0.8 \mathrm{mV}$ ) as well as in the number of responding cells (Fig. 4F: $\mathrm{CB}_{2} \mathrm{R}$ KO: 2/12; $\mathrm{CB}_{2} \mathrm{R}$ WT: 9/12).

Corresponding phenotypes were also observed in recordings of PCs in transgenic CB-R knockout animals: in $\mathrm{CB}_{1} \mathrm{R}$-deficient mice and their WT littermates trains of APs induced SSI of similar magnitude $\left(\mathrm{CB}_{1} \mathrm{R}\right.$ WT: $\Delta \mathrm{V}_{\mathrm{m}}:-3.9 \pm 0.9 \mathrm{mV} ; \mathrm{CB}_{1} \mathrm{R}$ KO: $\Delta \mathrm{V}_{\mathrm{m}}:-4.2 \pm 1.5 \mathrm{mV}$; Suppl. Fig. 2). In contrast, the genetic deletion of $\mathrm{CB}_{2} \mathrm{Rs}$ abolishes SSI also in PCs $\left(\mathrm{CB}_{2} \mathrm{R}\right.$ $\mathrm{WT}: \Delta \mathrm{V}_{\mathrm{m}}:-6.1 \pm 1.7 \mathrm{mV} ; \mathrm{CB}_{2} \mathrm{R} \mathrm{WT}: \Delta \mathrm{V}_{\mathrm{m}}:-0.5 \pm 0.6 \mathrm{mV}$; Suppl. Fig. 2).

Finally, we tested the specificity of the $\mathrm{CB}_{2} \mathrm{R}$ agonist $\mathrm{HU}-308$ for inducing a long-lasting hyperpolarization in RSNPCs. In $\mathrm{CB}_{1} \mathrm{R}$-deficient mice as well as in their corresponding littermates, HU-308 application mimicked AP-induced SSI while it failed to hyperpolarize RSNPCs in $\mathrm{CB}_{2} \mathrm{R}$-deficient mice (Fig. $4 \mathrm{G}-\mathrm{I}: \mathrm{CB}_{1} \mathrm{R}$ KO: $\Delta \mathrm{V}_{\mathrm{m}}:-4.9 \pm 1.9 \mathrm{mV} 7 / 10$ responsive cells; $\mathrm{CB}_{1} \mathrm{R}$ WT: $\Delta \mathrm{V}_{\mathrm{m}}:-5.5 \pm 1.6 \mathrm{mV}, 7 / 10$ responsive cells; $\mathrm{CB}_{2} \mathrm{R}$ KO: $\Delta \mathrm{V}_{\mathrm{m}}: 0.5 \pm 1.5 \mathrm{mV}$, 0/8 responsive cells; $\mathrm{CB}_{2} \mathrm{R} W \mathrm{WT}: \Delta \mathrm{V}_{\mathrm{m}}:-4.1 \pm 1.8 \mathrm{mV}, 7 / 11$ responsive cells). These experiments rule out potential off-target effects of HU-308 in the induction of SSI, and underlie establish its specificity for $\mathrm{CB}_{2} \mathrm{R}$ at a concentration of $1 \mu \mathrm{M}$.

Taken together, both pharmacological intervention and genetic ablation of $\mathrm{CB}_{2} \mathrm{Rs}$ confirm the involvement of $\mathrm{CB}_{2} \mathrm{Rs}$ in $\mathrm{SSI}$ of layer $2 / 3$ regular spiking cells, providing strong evidence that cell-autonomous activation of $\mathrm{CB}_{2} \mathrm{Rs}$ and downstream GIRK channel opening is mediating the AP-induced self-inhibition in these cell types. 


\section{Discussion}

Here, we show that trains of APs induce SSI in RSNPCs and PCs in layer $2 / 3$ of the somatosensory cortex but not in FS interneurons. This cell type-specific expression of SSI was also described for layer 5 of the somatosensory cortex, where only LTS interneurons, but not FS neurons exhibited SSI (Bacci et al., 2004). In RSNPCs of layer 2/3 we investigated the underlying mechanism in detail using pharmacological tools as well as $C B_{1} R$ - and $C B_{2} R$-deficient mice. We find that $S S I$ is selectively mediated by $C B_{2} R s$ in both RSNPCs as well as PCs. This is somewhat unexpected as $\mathrm{CB}_{1} \mathrm{Rs}$ have been previously implicated in SSI of PCs in layer 2/3 of somatosensory cortex (Marinelli et al., 2009).

Several recent studies have described the role of $\mathrm{CB}_{2} \mathrm{Rs}$ in cellular auto-inhibition: In hippocampal pyramidal neurons $\mathrm{CB}_{2} \mathrm{Rs}$ mediate SSI after trains of APs (Stempel et al., 2016). Additionally, intracellular $\mathrm{CB}_{2} \mathrm{Rs}$ were also shown to reduce firing frequency in PCs of the prefrontal cortex (den Boon et al., 2012). Furthermore, application of $\mathrm{CB}_{2} \mathrm{R}$ agonists hyperpolarizes dissociated dopaminergic neurons of the ventral tegmental area and inhibits spiking (Zhang et al., 2014). Together these findings illustrate that $C_{2} R$ activation can lead to modifications in excitability in several different cell types and in different brain regions.

What are the signaling events downstream of the endocannabinoid receptors that lead to SSI? So far, several mechanisms have been identified: In hippocampal PCS SSI is mediated by $\mathrm{CB}_{2} \mathrm{R}$-induced NBC transporter activation (Stempel et al., 2016). In contrast, $\mathrm{CB}_{1} \mathrm{R}$-mediated GIRK channel activation was described as the mechanism responsible for SSI in layer 2/3 PCs and layer 5 LTS interneurons (Bacci et al., 2004; Marinelli et al., 2009). In the present study, we demonstrate a different pathway for SSI in RSNPCs of layer $2 / 3$ and show that $A P s$ lead to the activation of $\mathrm{CB}_{2} \mathrm{Rs}$, resulting in the opening of GIRK channels and hyperpolarization of the membrane potential. 
In addition to the cell type-specific preference for endocannabinoid receptor subtypes in SSI activation, divergent intracellular transduction pathways are also employed to hyperpolarize the membrane potential. Given the variability of receptor and receptor subtype expression across different classes of neurons, it is not surprising that multiple mechanisms and downstream signaling cascades are involved in phenomena such as SSI (Arey, 2014). Further, several studies have shown that $\mathrm{CB}_{2} \mathrm{Rs}$ activation can lead to selective utilization of different transduction pathways (Atwood et al., 2012; Dhopeshwarkar and Mackie, 2016). Thus, cell type specific variations of the intracellular signaling machinery may determine which transduction pathway is implemented after agonist binding.

Due to the low $\mathrm{CB}_{2} \mathrm{R}$ expression levels in neuronal cells under physiological conditions, it has been a challenging task to study $C N S$ effects of $C_{2} R$. Unspecific $C B_{1} R$-pharmacology (Stempel et al., 2016) and $\mathrm{CB}_{2} \mathrm{R}$ antibodies of insufficient specificity (Cécyre et al., 2014; Marchalant et al., 2014) have previously impeded a convincing discrimination between $\mathrm{CB}_{1} \mathrm{R}$ - and $\mathrm{CB}_{2} \mathrm{R}$-mediated effects in the $\mathrm{CNS}$. However, in recent years, evidence accumulated suggesting that both $\mathrm{CB}_{1}{ }^{-}$and $\mathrm{CB}_{2} \mathrm{Rs}$ serve divergent physiological effects. Stempel et al. (Stempel et al., 2016) and Chen et al. (Chen et al., 2017) proposed that $\mathrm{CB}_{1} \mathrm{Rs}$ seem to be mainly involved in modulation of synaptic functions while $C_{2} R$ activation results in postsynaptic inhibition. Additionally, microglial $\mathrm{CB}_{2} \mathrm{R}$ expression was shown to be involved and upregulated in a variety of pathological conditions including neuroinflammation (Carlisle et al., 2002; Zoppi et al., 2014), stroke (Yu et al., 2015; Zarruk et al., 2012), Parkinson's disease (Concannon et al., 2016, 2015), Alzheimer's (Benito et al., 2003) and Huntington's disease (Palazuelos et al., 2009). Also, neuronal $\mathrm{CB}_{2} \mathrm{R}$ expression is increased in neuropathic pain (Sviženská et al., 2013) and drug addiction (Zhang et al., 2016). Manipulation of $\mathrm{CB}_{2} \mathrm{R}$ expression in CA1 PC or microglia was shown to induce distinct behavioral phenotypes in mice: while microglial $C_{2} R s$ 
were involved in contextual fear memory, overexpression or disruption of $\mathrm{CB}_{2} \mathrm{Rs}$ in $\mathrm{PC}$ lowered anxiety levels or enhanced spatial working memory, respectively (Li and Kim, 2017). Moreover, constitutive deletion of $\mathrm{CB}_{2} \mathrm{Rs}$ induces a schizophrenic phenotype in mice (Ortega-Alvaro et al., 2011), increases aggressive behavior (Rodríguez-Arias et al., 2015) and modulates drug-seeking behavior for ethanol (Ortega-Álvaro et al., 2015) and nicotine (Navarrete et al., 2013). Furthermore, neuronal $\mathrm{CB}_{2} \mathrm{Rs}$ modulate oscillatory activity - more specific theta-gamma-coupling - in the hippocampal formation (Stempel et al., 2016).

According to these data, Pacher and Machoulam (Pacher and Mechoulam, 2011) suggested that $\mathrm{CB}_{2} \mathrm{R}$ signaling might represent a protective system that prevents tissue and cell damage. In line with this, the $\mathrm{CB}_{2} \mathrm{R}$ mediated auto-inhibition described here may represent a cell-autonomous feedback loop preventing neurons from damage due to excessive excitability. In this study, the SSI-induced hyperpolarization is indiscriminately observed in both types of regular spiking neurons. In contrast, fast spiking interneurons do not show this phenomenon, which argues in favor of a protective role against intolerable amounts of excitation. In addition, on a more speculative note, it is likely that RSNPCS belong to a group of interneurons (5- $\mathrm{HT}_{3 \mathrm{~A}}$ receptor containing), which preferentially synapse onto other interneurons (Tremblay et al., 2016). Thus, silencing RSPNCs would lead to disinhibition of interneurons, effectively adding to the excitation protection of PCs. The long-term stability of SSI after induction is a further indication that it might occur in specific events where neurons must be prevented from excessive activity levels for a longer period of time.

In terms of the physiological relevance of the phenomenon under study, it has been shown before that SSI can also be induced with more naturally spaced activity patterns than the induction patterns used in this study: physiological spike trains from in vivo 
recordings were applied in slices and induced SSI in CA3 pyramidal neurons of similar magnitude like the more artificial AP trains (Stempel et al., 2016). Similarly, Marinelli et al. could reliably induce SSI in cortical PC with spike trains of lower $(10-50 \mathrm{~Hz})$ frequencies (Marinelli et al., 2009). In this context it is noteworthy that for somatosensory cortex layer $2 / 3$ regular spiking pyramidal neurons, firing frequencies of up to $60 \mathrm{~Hz}$ have been reported (Kinnischtzke et al., 2012). Therefore, SSI can already be induced by activity patterns of neurons that can occur in vivo. However, the specific role of SSI under physiological conditions has to be addressed experimentally in more detail.

Together with the lack of psychoactive effects upon $C_{2} R$ activation and other $C B_{1} R$ activation-related side effects (Pertwee, 2012), these findings highlight that $\mathrm{CB}_{2} \mathrm{Rs}$ represent an excellent target for drug-discovery research for multiple pathological conditions.

\section{Conclusion}

Our study describes a new mechanism by which SSI is implemented in neocortical neurons. We show that $\mathrm{CB}_{2} \mathrm{R}$ activation leads to a GIRK channel mediated cellautonomous hyperpolarization and provide further evidence for functional $\mathrm{CB}_{2} \mathrm{Rs}$ in the CNS and supporting their role in regulation of neuronal excitability. Future studies combining different techniques will aid in disentangling the different roles of $\mathrm{CB}_{1} \mathrm{Rs}$ and $\mathrm{CB}_{2} \mathrm{Rs}$, resulting in a better understanding of their functions and helping the discovery of specific therapeutic targets for different pathological conditions. 


\section{Acknowledgments}

This work was supported by the NeuroCure Cluster of Excellence (grand number EXC 257), the Bernstein Center for Computational Neuroscience (grand number 01GQ1001A), the Deutsche Zentrum für neurodegenerative Erkrankungen, the Einstein Foundation and the Deutsche Forschungsgemeinschaft (grand numbers SFB958, SPP1926). The study was conceived and designed by D.S. and A.S., who also wrote the paper. A.S. performed all experiments with the help of D.P., R.P.S., and A.S. analyzed all experiments. A.V.S., J.B and B.R.R. contributed to validation and formal analysis as well as reviewing and editing of this study.

\section{$\underline{\text { References }}$}

Arey, B.J., 2014. Biased Signaling in Physiology, Pharmacology and Therapeutics. Elsevier Academic Press, Amsterdam (Netherlands). https://doi.org/10.1016/B978-0-12-411460-9.00012-4

Atwood, B.K., Wager-Miller, J., Haskins, C., Straiker, A., Mackie, K., 2012.

Functional selectivity in $\mathrm{CB} 2$ cannabinoid receptor signaling and Regulation: Implications for the Therapeutic Potential of CB2 ligands. Mol. Pharmacol. 81, 250-63. https://doi.org/10.1124/mol.111.074013

Bacci, A., Huguenard, J.R., Prince, D.A., 2004. Long-Lasting self-inhibition of neocortical interneurons mediated by endocannabinoids. Nature 431, 312316. https://doi.org/10.1038/nature02782.1.

Benito, C., Núñez, E., Tolón, R.M., Carrier, E.J., Rábano, A., Hillard, C.J., Romero, J., 2003. Cannabinoid CB2 receptors and fatty acid amide hydrolase are selectively overexpressed in neuritic plaque-associated glia in Alzheimer's disease brains. J. Neurosci. 23, 11136-11141. https://doi.org/23/35/11136 [pii]

Buckley, N.E., McCoy, K.L., Mezey, É., Bonner, T., Zimmer, A., Felder, C.C., Glass, M., Zimmer, A., 2000. Immunomodulation by cannabinoids is absent in mice deficient for the cannabinoid CB2receptor. Eur. J. Pharmacol. 396, 141-149. https://doi.org/10.1016/S0014-2999(00)00211-9

Carlisle, S.J., Marciano-Cabral, F., Staab, A., Ludwick, C., Cabral, G.A., 2002. Differential expression of the CB2 cannabinoid receptor by rodent macrophages and macrophage-like cells in relation to cell activation. Int. Immunopharmacol. 2, 69-82. https://doi.org/10.1016/S15675769(01)00147-3 
Cécyre, B., Thomas, S., Ptito, M., Casanova, C., Bouchard, J.F., 2014. Evaluation of the specificity of antibodies raised against cannabinoid receptor type 2 in the mouse retina. Naunyn. Schmiedebergs. Arch. Pharmacol. 387, 175-184. https://doi.org/10.1007/s00210-013-0930-8

Chen, D., Gao, M., Gao, F., Su, Q., Wu, J., 2017. Brain cannabinoid receptor 2: expression, function and modulation. Acta Pharmacol. Sin. 38, 312-316. https://doi.org/10.1038/aps.2016.149

Chevaleyre, V., Castillo, P.E., 2003. Heterosynaptic LTD of hippocampal GABAergic synapses: A novel role of endocannabinoids in regulating excitability. Neuron 38, 461-472. https://doi.org/10.1016/S08966273(03)00235-6

Concannon, R.M., Okine, B.N., Finn, D.P., Dowd, E., 2016. Upregulation of the cannabinoid CB2 receptor in environmental and viral inflammation-driven rat models of Parkinson's disease. Exp. Neurol. 283, 204-212. https://doi.org/10.1016/j.expneurol.2016.06.014

Concannon, R.M., Okine, B.N., Finn, D.P., Dowd, E., 2015. Differential upregulation of the cannabinoid CB2 receptor in neurotoxic and inflammation-driven rat models of Parkinson's disease. Exp. Neurol. 269, 133-141. https://doi.org/10.1016/j.expneurol.2015.04.007

den Boon, F.S., Chameau, P., Schaafsma-Zhao, Q., van Aken, W., Bari, M., Oddi, S., Kruse, C.G., Maccarrone, M., Wadman, W.J., Werkman, T.R., 2012. Excitability of prefrontal cortical pyramidal neurons is modulated by activation of intracellular type-2 cannabinoid receptors. Proc. Natl. Acad. Sci. U. S. A. 109, 3534-9. https://doi.org/10.1073/pnas.1118167109

Dhopeshwarkar, A., Mackie, K., 2016. Functional Selectivity of CB2 Cannabinoid Receptor Ligands at a Canonical and Noncanonical Pathway. J. Pharmacol. Exp. Ther. 358, 342-351. https://doi.org/10.1124/jpet.116.232561

Feng, L., Zhao, T., Kim, J., 2015. neuTube 1.0: A New Design for efficient Neuron reconstruction Software Based on the SWC Format. eNeuro 2, 1-10. https://doi.org/10.1523/JNEUROSCI.2055-07.2007

García-Gutiérrez, M.S., García-Bueno, B., Zoppi, S., Leza, J.C., Manzanares, J., 2012. Chronic blockade of cannabinoid CB 2 receptors induces anxiolyticlike actions associated with alterations in GABA A receptors. Br. J. Pharmacol. 165, 951-964. https://doi.org/10.1111/j.14765381.2011.01625.x

García-Gutiérrez, M.S., Ortega-Álvaro, A., Busquets-García, A., Pérez-Ortiz, J.M., Caltana, L., Ricatti, M.J., Brusco, A., Maldonado, R., Manzanares, J., 2013. Synaptic plasticity alterations associated with memory impairment induced by deletion of CB2 cannabinoid receptors. Neuropharmacology 73, 388396. https://doi.org/10.1016/j.neuropharm.2013.05.034

Gerdeman, G.L., Ronesi, J., Lovinger, D.M., 2002. Postsynaptic endocannabinoid release is critical to long-term depression in the striatum. Nat. Neurosci. 5, 446-451. https://doi.org/10.1038/nn832

Gómez-Gonzalo, M., Navarrete, M., Perea, G., Covelo, A., Martín-Fernández, M., Shigemoto, R., Luján, R., Araque, A., 2015. Endocannabinoids induce lateral long-term potentiation of transmitter release by stimulation of gliotransmission. Cereb. Cortex 25, 3699-3712. 
https://doi.org/10.1093/cercor/bhu231

Gong, J.P., Onaivi, E.S., Ishiguro, H., Liu, Q.R., Tagliaferro, P.A., Brusco, A., Uhl, G.R., 2006. Cannabinoid CB2 receptors: Immunohistochemical localization in rat brain. Brain Res. 1071, 10-23.

https://doi.org/10.1016/j.brainres.2005.11.035

Hanus, L., Abu-Lafi, S., Fride, E., Breuer, A., Vogel, Z., Shalev, D.E., Kustanovich, I., Mechoulam, R., 2001. 2-Arachidonyl glyceryl ether, an endogenous agonist of the cannabinoid CB1 receptor. Proc. Natl. Acad. Sci. 98, 3662-3665. https://doi.org/10.1073/pnas.061029898

Kano, M., 2009. Endocannabinoid-mediated control of synaptic transmission. Physiol Rev 89, 309-380. https://doi.org/10.1152/physrev.00019.2008.

$\mathrm{Kim}, \mathrm{J.,}$ Li, Y., 2015. Chronic activation of CB2 cannabinoid receptors in the hippocampus increases excitatory synaptic transmission. J. Physiol. 593, 871-886. https://doi.org/10.1113/jphysiol.2014.286633

Kinnischtzke, A.K., Sewall, A.M., Berkepile, J.M., Fanselow, E.E., 2012. Postnatal maturation of somatostatin-expressing inhibitory cells in the somatosensory cortex of GIN mice. Front. Neural Circuits 6, 1-12.

https://doi:10.3389/fncir.2012.00033

Kreitzer, a C., Regehr, W.G., 2001. Cerebellar depolarization-induced suppression of inhibition is mediated by endogenous cannabinoids. J. Neurosci. 21, RC174. https://doi.org/20015720 [pii]

Li, Y., Kim, J., 2017. Distinct roles of neuronal and microglial CB2 cannabinoid receptors in the mouse hippocampus. Neuroscience 363, 11-25. https://doi.org/10.1016/j.neuroscience.2017.08.053

Maglio, L.E., Noriega-Prieto, J.A., Maraver, M.J., Fernández de Sevilla, D., 2017. Endocannabinoid-Dependent Long-Term Potentiation of Synaptic Transmission at Rat Barrel Cortex. Cereb. Cortex 1-14. https://doi.org/10.1093/cercor/bhx053

Marchalant, Y., Brownjohn, P.W., Bonnet, A., Kleffmann, T., Ashton, J.C., 2014. Validating Antibodies to the Cannabinoid CB2 Receptor: Antibody Sensitivity Is Not Evidence of Antibody Specificity. J. Histochem. Cytochem. 62, 395404. https://doi.org/10.1369/0022155414530995

Marinelli, S., Pacioni, S., Cannich, A., Marsicano, G., Bacci, A., 2009. Selfmodulation of neocortical pyramidal neurons by endocannabinoids. Nat. Neurosci. 12, 1488-1490. https://doi.org/10.1038/nn.2430

Munro, S., Thomas, K.L., Abu-Shaar, M., 1993. Molecular characterization of a peripheral receptor for cannabinoids. Nature 365, 61-65. https://doi.org/10.1038/365061a0

Navarrete, F., Rodríguez-Arias, M., Martín-García, E., Navarro, D., GarcíaGutiérrez, M.S., Aguilar, M.A., Aracil-Fernández, A., Berbel, P., Miñarro, J., Maldonado, R., Manzanares, J., 2013. Role of CB2 cannabinoid receptors in the rewarding, reinforcing, and physical effects of nicotine.

Neuropsychopharmacology 38, 2515-2524. https://doi.org/10.1038/npp.2013.157

Ohno-Shosaku, T., Maejima, T., Kano, M., 2001. Endogenous cannabinoids mediate retrograde signals from depolarized postsynaptic neurons to presynaptic terminals. Neuron 29, 729-738. https://doi.org/10.1016/S0896- 


\section{3(01)00247-1}

Onaivi, E.S., 2007. Neuropsychobiological evidence for the functional presence and expression of cannabinoid CB2 receptors in the brain.

Neuropsychobiology 54, 231-246. https://doi.org/10.1159/000100778

Ortega-Alvaro, A., Aracil-Fernández, A., García-Gutiérrez, M.S., Navarrete, F., Manzanares, J., 2011. Deletion of CB2 Cannabinoid Receptor Induces Schizophrenia-Related Behaviors in Mice. Neuropsychopharmacology 36, 1489-1504. https://doi.org/10.1038/npp.2011.34

Ortega-Álvaro, A., Ternianov, A., Aracil-Fernández, A., Navarrete, F., GarcíaGutiérrez, M.S., Manzanares, J., 2015. Role of cannabinoid CB2receptor in the reinforcing actions of ethanol. Addict. Biol. 20, 43-55. https://doi.org/10.1111/adb.12076

Pacher, P., Mechoulam, R., 2011. Is lipid signaling through cannabinoid 2 receptors part of a protective system? Prog. Lipid Res. 50, 193-211. https://doi.org/10.1016/j.plipres.2011.01.001

Palazuelos, J., Aguado, T., Pazos, M.R., Julien, B., Carrasco, C., Resel, E., Sagredo, O., Benito, C., Romero, J., Azcoitia, I., Fernández-Ruiz, J., Guzmán, M., GalveRoperh, I., 2009. Microglial CB2cannabinoid receptors are neuroprotective in Huntington's disease excitotoxicity. Brain 132, 3152-3164.

https://doi.org/10.1093/brain/awp239

Pertwee, R.G., 2012. Targeting the endocannabinoid system with cannabinoid receptor agonists: pharmacological strategies and therapeutic possibilities. Philos. Trans. R. Soc. B Biol. Sci. 367, 3353-3363. https://doi.org/10.1098/rstb.2011.0381

Rodríguez-Arias, M., Navarrete, F., Blanco-Gandia, M.C., Arenas, M.C., Aguilar, M.A., Bartoll-Andrés, A., Valverde, O., Miñarro, J., Manzanares, J., 2015. Role of CB2 receptors in social and aggressive behavior in male mice. Psychopharmacology (Berl). 232, 3019-3031. https://doi.org/10.1007/s00213-015-3939-5

Safo, P.K., Regehr, W.G., 2005. Endocannabinoids control the induction of cerebellar LTD. Neuron 48, 647-659. https://doi.org/10.1016/j.neuron.2005.09.020

Schindelin, J., Arganda-Carreras, I., Frise, E., Kaynig, V., Longair, M., Pietzsch, T., Preibisch, S., Rueden, C., Saalfeld, S., Schmid, B., Tinevez, J.-Y.J.-Y., White, D.J., Hartenstein, V., Eliceiri, K., Tomancak, P., Cardona, A., Liceiri, K., Tomancak, P., A., C., 2012. Fiji: An open source platform for biological image analysis. Nat. Methods 9, 676-682. https://doi.org/10.1038/nmeth.2019.Fiji

Sjöström, P.J., Turrigiano, G.G., Nelson, S.B., 2003. Neocortical LTD via coincident activation of presynaptic NMDA and cannabinoid receptors. Neuron 39, 641-654. https://doi.org/10.1016/S0896-6273(03)00476-8

Stempel, A.V., Stumpf, A., Zhang, H.Y., Özdoğan, T., Pannasch, U., Theis, A.K., Otte, D.M., Wojtalla, A., Rácz, I., Ponomarenko, A., Xi, Z.X., Zimmer, A., Schmitz, D., 2016. Cannabinoid Type 2 Receptors Mediate a Cell TypeSpecific Plasticity in the Hippocampus. Neuron 90, 795-809. https://doi.org/10.1016/j.neuron.2016.03.034

Svíženská, I.H., Brázda, V., Klusáková, I., Dubový, P., 2013. Bilateral Changes of Cannabinoid Receptor Type 2 Protein and mRNA in the Dorsal Root Ganglia 
of a Rat Neuropathic Pain Model. J. Histochem. Cytochem. 61, 529-547. https://doi:10.1016/j.neuron.2016.06.033

Tremblay, R., Soohyun. L., Rudy, B., 2016. GABAergic Interneurons in the Neocortex: From Cellular Properties to Circuits. Neuron 91, 260-292 https://doi.org/10.1016/j.neuron.2016.03.034

Wang, W., Trieu, B.H., Palmer, L.C., Jia, Y., Pham, D.T., Jung, K.-M., Karsten, C.A., Merrill, C.B., Mackie, K., Gall, C.M., Piomelli, D., Lynch, G., 2016. A Primary Cortical Input to Hippocampus Expresses a Pathway-Specific and Endocannabinoid-Dependent Form of Long-Term Potentiation. eNeuro 3, 160-16. https://doi.org/10.1523/ENEURO.0160-16.2016

Wilson, R.I., Nicoll, R. a, 2001. Endogenous cannabinoids mediate retrograde signalling at hippocampal synapses. Nature 410, 588-592. https://doi.org/10.1038/35069076

Yu, S.J., Reiner, D., Shen, H., Wu, K.J., Liu, Q.R., Wang, Y., 2015. Time-dependent protection of CB2 receptor agonist in stroke. PLoS One 10, 1-17. https://doi.org/10.1371/journal.pone.0132487

Zarruk, J.G., Fernández-López, D., García-Yébenes, I., García-Gutiérrez, M.S., Vivancos, J., Nombela, F., Torres, M., Burguete, M.C., Manzanares, J., Lizasoain, I., Moro, M.A., 2012. Cannabinoid type 2 receptor activation downregulates stroke-induced classic and alternative brain macrophage/microglial activation concomitant to neuroprotection. Stroke 43, 211-219. https://doi.org/10.1161/STROKEAHA.111.631044

Zhang, H.-Y., Gao, M., Liu, Q.-R., Bi, G.-H., Li, X., Yang, H.-J., Gardner, E.L., Wu, J., $X i$, Z.-X., 2014. Cannabinoid CB2 receptors modulate midbrain dopamine neuronal activity and dopamine-related behavior in mice. Proc. Natl. Acad. Sci. U. S. A. 111, E5007-5015. https://doi.org/10.1073/pnas.1413210111

Zhang, H.-Y., Gao, M., Shen, H., Bi, G.-H., Yang, H.-J., Liu, Q.-R., Wu, J., Gardner, E.L., Bonci, A., Xi, Z.-X., 2016. Expression of functional cannabinoid CB2 receptor in VTA dopamine neurons in rats. Addict. Biol. 22, 752-765. https://doi.org/10.1111/adb.12367

Zimmer, a M., Hohmann, a G., Herkenham, M., Bonner, T.I., 1999. Increased mortality, hypoactivity, and hypoalgesia in cannabinoid CB1 receptor knockout mice. Proc. Natl. Acad. Sci. U. S. A. 96, 5780-5785. https://doi.org/10.1073/pnas.96.10.5780

Zoppi, S., Madrigal, J.L., Caso, J.R., García-Gutiérrez, M.S., Manzanares, J., Leza, J.C., García-Bueno, B., 2014. Regulatory role of the cannabinoid CB2 receptor in stress-induced neuroinflammation in mice. Br. J. Pharmacol. 171, 2814-2826. https://doi.org/10.1111/bph.12607 


\section{Captions}

Fig. 1. Trains of APs induce cell type-specific hyperpolarization in regular firing neurons in layer II/III of somatosensory cortex.

A - C) Characteristic cell morphology and firing pattern of a PC (A), an RSNPC (B) and a FS interneuron (C), visualized by post-hoc biocytin staining and reconstruction. Scale bar: $50 \mu \mathrm{m}$; arrow heads depict the direction of the pial surface. Insets show neuron-typespecific firing patterns evoked by depolarizing current injection (scale bars: $20 \mathrm{mV}, 0.2$ s). $D-I)$ Single cell examples (D - F) and time course of the average membrane potential ( $G$ -1) before, during and after ten trains of APs (black lines) in the different cell types.

$J-L)$ Individual magnitudes of the AP-train induced hyperpolarization. Trains of APs induce SSI in PCS $(D, G, J ; n=11)$ and in RSNPCS $(E, H, K ; n=21)$, but not in FS interneurons $(\mathrm{F}, \mathrm{I}, \mathrm{L} ; n=6)$. 
Fig. 2. AP-induced hyperpolarization is accompanied by a reduction in input resistance that is mediated by activation of GIRK-channels in RSNPCs.

A) The amplitude of the hyperpolarization $\left(\Delta \mathrm{V}_{\mathrm{m}}\right)$ correlates with the reduction in input resistance (normalized to the pre-AP average; $r^{2}=0.81, p<0.0001$ ). Inset: example traces of $-40 \mathrm{pA}$ testpulses before and after AP trains; scale bars: $0.2 \mathrm{~s}, 5 \mathrm{mV}$; filled circle in the plot depicts example recording.

B) Inhibition of AP-induced hyperpolarization by preincubation with the GIRK channel blocker SCH23390 (10 $\mu \mathrm{M}$; B; black lines mark AP stimulation). C) SCH23390 reduced the average SSI magnitude $\left({ }^{* * *} p=0.0005\right.$, Student's t-test; control $n=21 ; \mathrm{SCH} 23390 n=$ 11) as well as percentage of hyperpolarizing cells (D).

E) Single cell example of the depolarization induced by application of SCH23390 (10 $\mu \mathrm{M})$ after AP-induced SSI, compared to a control recording without $\mathrm{SCH} 23390$ application.

F) Summary of the SCH23390 effect on the membrane potential after SSI induction ( $n=$ $5)$.

G) Application of $\mathrm{SCH} 2330$ on non-stimulated cells (on baseline) causes only a minor depolarization ( ${ }^{*} p=0.0159$ Mann-Whitney test; on baseline: $n=4$; after SSI: $n=5$ ) compared to the effect after SSI. 
Fig. 3. Pharmacological experiments indicate involvement of $C_{2} R$ in RSNPC SSI.

A) Time course of the average membrane potential in response to application of the specific $\mathrm{CB}_{2} \mathrm{R}$ agonist $\mathrm{HU}-308(1 \mu \mathrm{M})$ and the endocannabinoid $\mathrm{NE}(300 \mathrm{nM})$ that displays a selectivity for $\mathrm{CB}_{1} \mathrm{Rs}$ over $\mathrm{CB}_{2} \mathrm{Rs}$. Agonist application is indicated by the black line.

B) Individual magnitudes of agonist-induced hyperpolarization. NE does not cause a hyperpolarization (** $p=0.005$, Mann-Whitney rest; HU-308: $n=10 ;$ NE: $n=11$ ).

C) Time course of the average membrane potential before, during (black lines) and after AP trains in presence or absence of the $C_{2} R$ inverse agonist SR $144528(1 \mu M)$.

D) Individual magnitudes of AP-induced hyperpolarization in the presence of SR 144528. Preincubation with SR 144528 prevents AP-induced hyperpolarization (** $p=0.0019$, Mann-Whitney rest; SR 144528: $n=15$; control: $n=21$ ).

Fig. 4. AP-induced hyperpolarization in RSNPCs is absent in $C B_{2} R$-deficient mice but present in $\mathrm{CB}_{1} \mathrm{R}$-deficient mice.

$A-C)$ AP-induced SSI in RSNPCS of $C_{1} R$-deficient mice is indistinguishable from $S S I$ in WT-littermates ( $p=0.4$ Student's t-test; $\mathrm{CB}_{1} \mathrm{R}$ KO $n=17 ; \mathrm{CB}_{1} \mathrm{R}$ WT $n=10$ ). A) Time course of the average membrane potential in $\mathrm{WT}$ (open circles) and $\mathrm{CB}_{1} \mathrm{R}$ KO mice (black circles). B) Overview on individual magnitudes of AP-induced hyperpolarization. C) Percentage of cells in which AP trains evoked hyperpolarization. AP trains are indicated by black bars.

$D-F)$ Trains of APs failed to induced $S S I$ in $\mathrm{CB}_{2} \mathrm{R}$-deficient mice compared to WTlittermates (** $p=0.0029$ Student's t-test; $\mathrm{CB}_{2} \mathrm{R}$ KO $n=12 ; \mathrm{CB}_{2} \mathrm{R}$ WT $\left.n=12\right)$. D) Time 
course of the average membrane potential in WT (open circles) and $\mathrm{CB}_{2} \mathrm{R}$ KO mice (black circles). E) Individual magnitudes of the AP-induced hyperpolarization. F) Percentage of cells in which AP trains evoked a hyperpolarization. AP trains are indicated by black bars.

G - I) HU-308 (1 $\mu \mathrm{M})$ hyperpolarized RSNPCs in $\mathrm{CB}_{1} \mathrm{R}$ deficient mice and WT-littermates of transgenic animals ( $p=0.8$ Student's t-test; $\mathrm{CB}_{1} \mathrm{R}$ KO $n=10 ; \mathrm{CB}_{1} \mathrm{R}$ WT $n=10$ ), but not in $\mathrm{CB}_{2} \mathrm{R}$-deficient mice ( ${ }^{*} p=0.046 ; \mathrm{CB}_{2} \mathrm{R} \mathrm{KO} n=8 ; \mathrm{CB}_{2} \mathrm{R}$ WT $n=11$ ). G) Exemplary time course of the membrane potential of RSNPCs in response to HU-308 application (black line). Note the hyperpolarization in the $\mathrm{CB}_{1} \mathrm{R}$ KO (black circles), and the lack of hyperpolarization in the $\mathrm{CB}_{2} \mathrm{R}$ KO (black squares). $\mathrm{H}$ ) Individual magnitudes of agonistinduced hyperpolarization in different genotypes. I) Percentage of cells in which agonist application evoked hyperpolarization. 
Table 1: cell properties of cortical neurons in somatosensory cortex layer $2 / 3$

\begin{tabular}{llll} 
& PCs (11) & RSNPCs (21) & FSs (6) \\
\hline $\begin{array}{l}\text { Resting membrane } \\
\text { potential [mV] }\end{array}$ & $-81.9 \pm 2.0$ & $-80.6 \pm 1.2$ & $-65.2 \pm 1.9$ \\
$\begin{array}{l}\text { Input resistance }[\mathrm{MS}] \\
\text { AP half-width [ms] }\end{array}$ & $153.1 \pm 11.6$ & $189.3 \pm 13.87$ & $80,6 \pm 9.7$ \\
$\begin{array}{l}\text { AP threshold [mV] } \\
\text { AP slope ratio }\end{array}$ & $-33.9 \pm 1.3$ & $-36.0 \pm 1.0$ & $-46.8 \pm 2.6$ \\
$\begin{array}{l}\text { AHP [mV] } \\
\text { Maximal firing }\end{array}$ & $-16.5 \pm 0.2$ & $4.5 \pm 0.2$ & $0.9 \pm 0.1$ \\
frequency [Hz] & $36.8 \pm 2.3$ & $-15.0 \pm 0.5$ & $-18.1 \pm 0.6$ \\
\hline
\end{tabular}

Values are given as mean \pm SEM, PC: pyramidal cell; RSNPC: regular spiking non-pyramidal cell; FS: fast spiking interneuron; AHP: Afterhyperpolarization; numbers of recorded cells are displayed in parentheses. 

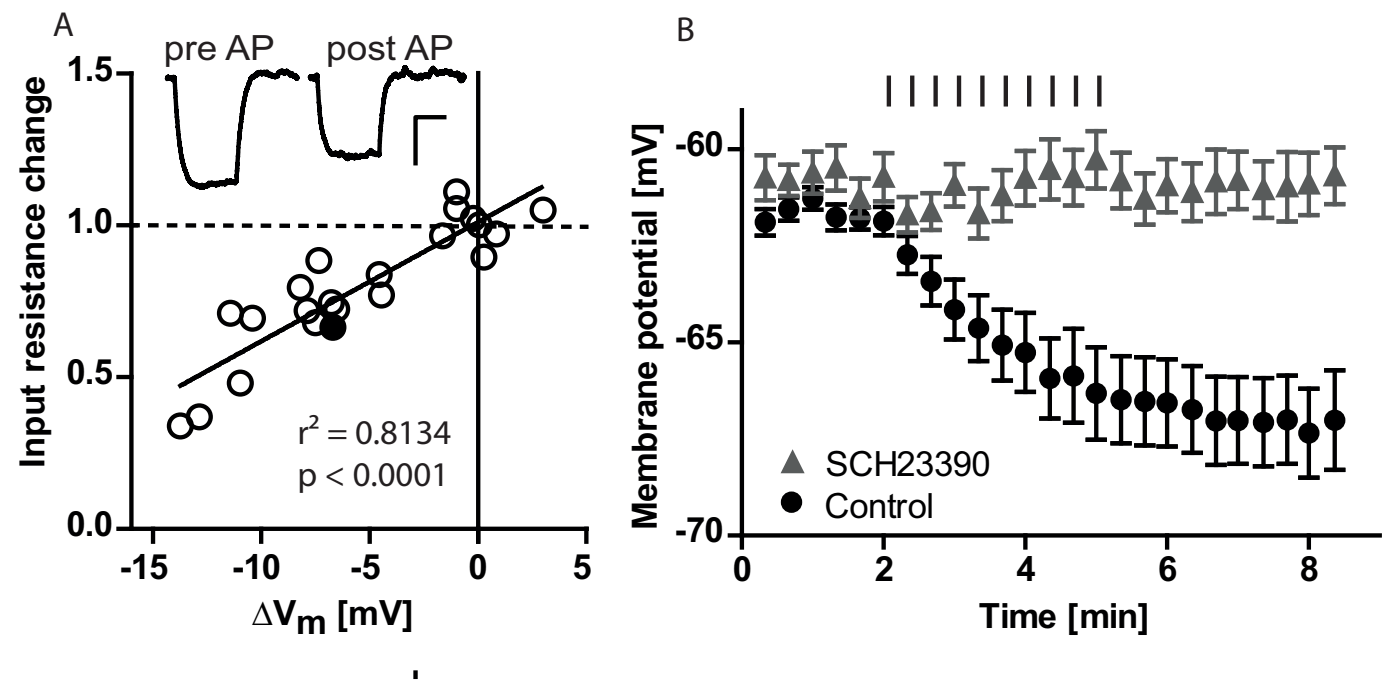
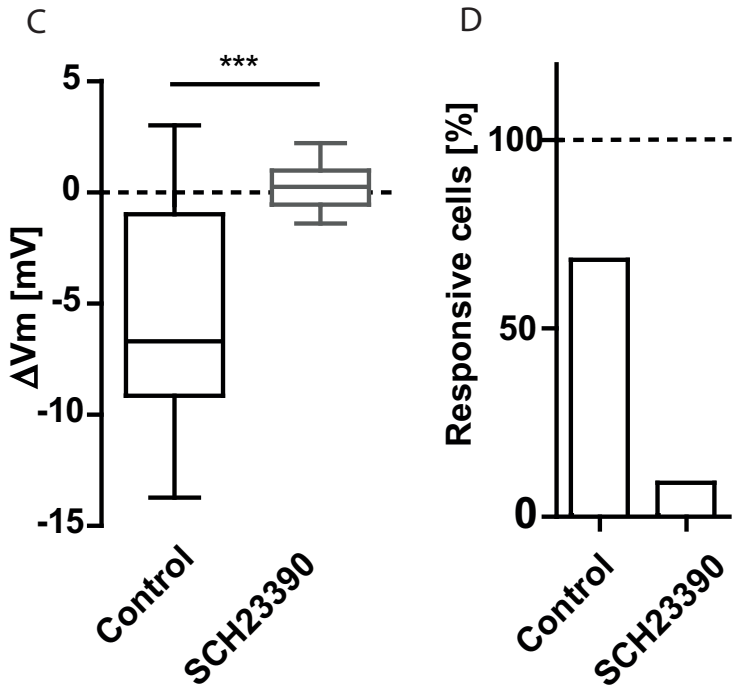

E

F

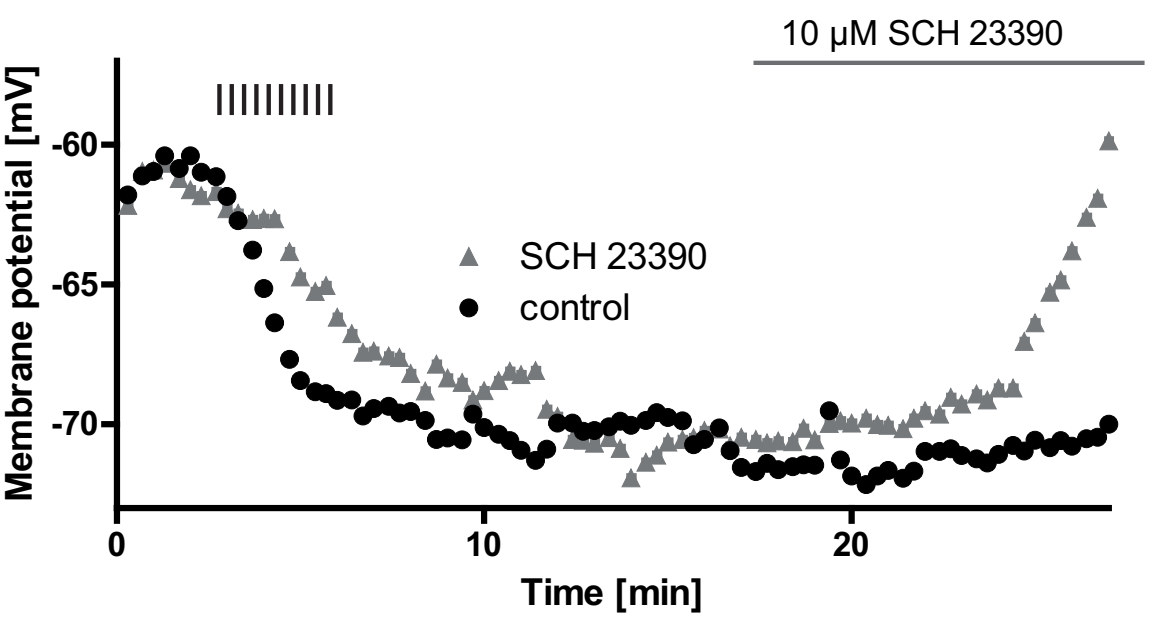

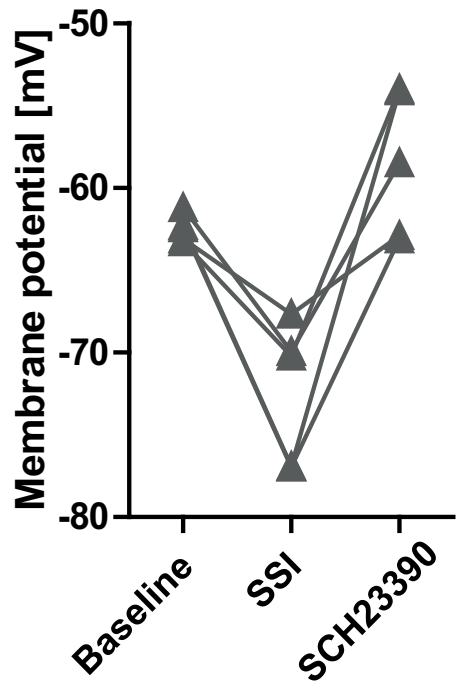

G

application of

$10 \mu \mathrm{M} \mathrm{SCH} 23390$

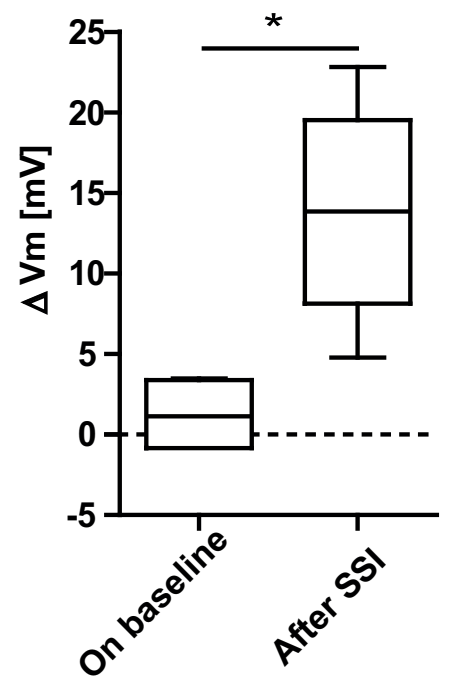




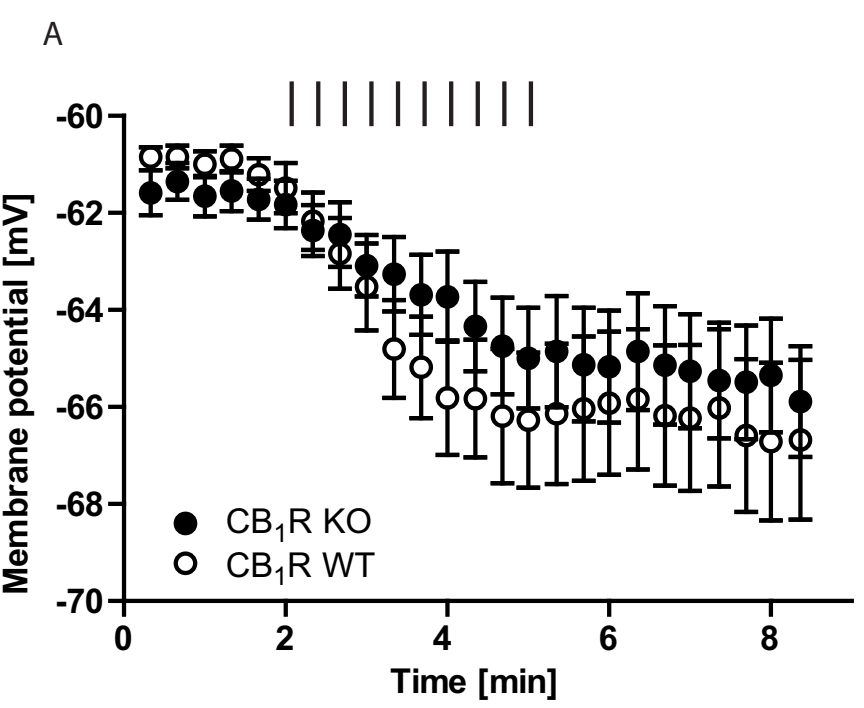

B
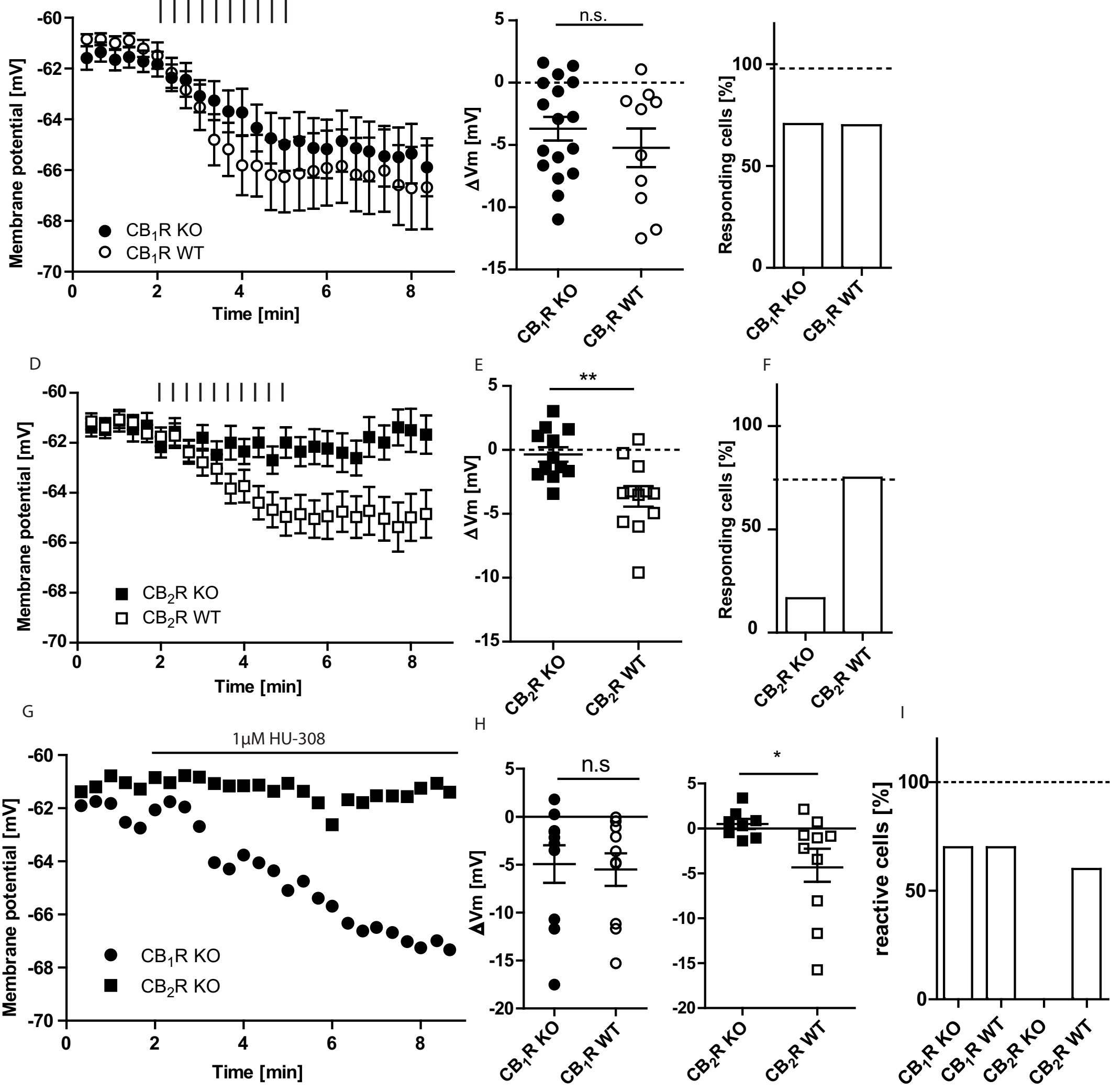
Supplementary Material
Click here to download Supplementary Material: Stumpf_Suppl Figure with legends.docx

Supplementary Material
Click here to download Supplementary Material: Stumpf_Suppl Figure with legends.docx ton

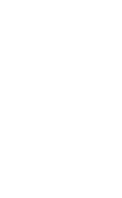

(1) (1) (1) (1) (1)

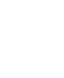

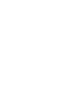

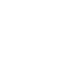
(1)

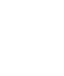
(1)

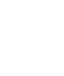
(1)

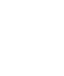
. . .

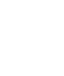

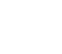

